\title{
Eye Surgeon
}

National Cancer Institute

\section{Source}

National Cancer Institute. Eye Surgeon. NCI Thesaurus. Code C17835.

A surgeon who specializes in treating diseases and disorders of the eyes. 